\title{
AN INDEX TO MEASURE RURAL DIVERSITY IN THE LIGHT OF RURAL RESILIENCE AND RURAL DEVELOPMENT DEBATE
}

\author{
Giovanni Quaranta1 ${ }^{1}$ Rosanna Salvia²
}

Received 20 June 2013; Accepted 14 March 2014

\begin{abstract}
Diversity has been extensively studied in ecological systems and its relationship with resilience has been well recognized. In social and ecological systems, in fact, diversity is considered key to determining resilience where resilience is defined as system's capacity to learn and adapt in the face of internal or external perturbations. However, although human and ecological systems are dynamic, interacting and interdependent, little attention has been given to social systems diversity and its implications. The interest in diversity and resilience of social-ecological systems is increasingly growing, particularly in the rural contexts, due to its possible effects on social and economic development and livelihoods. In this paper we define an analytical tool, the Rural Diversity Index (RDI), to assess the role of natural, economic and social diversity in determining alternative rural socio-ecological developmental patterns. The application of the RDI in pilot areas of Southern Italy showed that, in specific socio-ecological systems, higher natural-socio-economic diversity leads to higher degree of rural development, as measured through standard socio-economic indicators.
\end{abstract}

Key words: diversity, diversity index, resilience, rural development

\section{Introduction}

The concept of diversity has gained early attention in the field of ecology as related to the effects of biodiversity on ecosystems stability. The basic principle is that diversity, i.e. more types of species/elements in an ecosystem, makes ecosystems less vulnerable to environmental shocks and external threats (Kempener et al., 2009). Diversity enhances the stability and resilience of eco-systems because a small number of different elements is more vulnerable to disturbances and destructive oscillations than larger numbers (McCann, 2000). This fundamental principle remained largely unchallenged until the early 1970's when few authors began to argue that not all forms of diversity are positively associated with ecosystem resilience (McCann, 2000). It was later reported that more than the sheer number of species within an ecosystem, stability was largely affected by the interactions between the species and the number of functional groups (McCann, 2007).

\footnotetext{
${ }^{1}$ Prof. Giovanni Quaranta, Università degli Studi della Basilicata, DiMIE, Viale dell'Ateneo Lucano, 85100 Potenza, Italy; e-mail: giovanni.quaranta@unibas.it

2 Dr. Rosanna Salvia, Università degli Studi della Basilicata, DiMIE, Viale dell'Ateneo Lucano, 85100 Potenza, Italy; e-mail: sr606agr@unibas.it.
} 
Inspired by ecologists, the concept of diversity was subsequently adopted in a variety of fields to test whether greater diversity brings greater stability in other "systems", including social-, economic-, agro-systems and institutional settings (Kempener et al., 2009). Considering that any eco-system is very much intertwined with and dependent on the economic and social components of its local area, diversity began to be studied in the broader context of whole social-ecological systems (SES). It is now generally accepted that diversity in all its forms, including biodiversity, economic diversity (Wagner, 2002; Wagner and Deller, 1998) cultural diversity and social diversity, as well as institutional diversity (Ostrom, 2005) is a key requirement for long term sustainable functioning and adaptability of ecological and socioeconomic systems (Folke et al., 2002; Walker et al. 2006; Chavas and Di Falco, 2012; Chapin et al., 2009; Naeem et al., 2009).

Diversity can improve resilience in response to a variety of perturbations ranging from climate changes to economic crises. Many studies have been undertaken to address the relationship between diversity and ecosystem resilience, showing that biological diversity appears to enhance the resilience of desirable ecosystem states (Chapin et al., 1997; Elmqvist et al., 2003; Ives and Carpenter, 2007) and to support the flow of ecosystem goods and services under changing environmental conditions (Walker et al. 1999). Such perspectives on biological diversity have stimulated attempts to address institutional diversity and redundancy (Low et al. 2003; Ostrom, 2005; Folke, 2006). In addition to these benefits, diversity may involve some costs in both ecological and social contexts. As some scholars have pointed out (Anderies, 2006; Anderies et al., 2007; Janssen and Anderies, 2007; Janssen et al., 2007) effective governance under uncertainty must include the ongoing analysis of trade-offs between foregone short term benefits of high efficiency under narrowly constrained circumstances and the longterm persistence of the existing regime with reduced costs of crisis management (Anderies et al., 2006). Biggs et al., (2012) point out that particularly high levels of diversity can weaken the productivity of SES and thereby reduce resilience in the longer term. Diversity can also render systems less efficient which, in turn, leads to increased system stagnation (Lietaer et al., 2010; Ulanowicz et al., 2009). As diversity increases, the number of elements in the system also increases and, in time, this could lead to an exponential increase in the number of possible interactions between system elements (Ives and Carpenter, 2007). Social diversity, for instance, may weaken the capacity for collective action in resource management (Waring, 2011). In some circumstances, biological diversity may delay the ecosystem responses to adapt after a disturbance (Kinzig and Pacala, 2002). These costs have only been marginally addressed with respect to costs of social diversity (Nelson et al., 2011). The key to keeping resilience of SES is finding the right balance between system brittleness (associated with low levels of diversity) and system stagnation (associated with high levels of diversity) (Biggs et al., 2012). Because both efficiency and resilience are "indispensable for long-term sustainability and health, the healthiest flow systems are those that are closest to an optimal balance between these two opposing pulls. Conversely, an excess of either attribute leads to systemic instability. Too much efficiency leads to brittleness and too much resilience leads to stagnation: the former is caused by too little diversity and connectivity and the latter by too much diversity and connectivity. Sustainability of a complex flow system can therefore be defined as the optimal balance between efficiency and resilience of its network" (Lietaer et al., 2010).

Compared to simple eco-systems, in which diversity is directly related to genetic or biological diversity, SES present an additional level of complexity due to the coexistence of more diversities including those associated with knowledge, institutions, human opportunities and economic activities. Standard terminology within socio-ecological systems literature mainly refers to two categories: 1) Functional diversity, i.e. the number of functionally different groups present in a system and their effect on its performance; 2) Response Diversity, i.e. the range of responses the system possesses to disturbances (Walker et al., 2006). In this context, rural areas can be considered socio-ecological systems (Ambrosio-Albalá and Bastiaensen, 2010; Apeldoorn et al., 2011; Heijman et al., 2007; Schouten et al., 2009). For rural socio-ecological systems the level of complexity has a particular significance since these areas have been increasingly exposed in recent years to a vast array of changes and challenges ranging from disruption of fragile eco-systems to pressures on the stability of agricultural and forestry sectors. 
For these systems the functional role of diversity on resilience and rural development is largely unknown.

Methods to quantify diversity in socio-ecological systems should simultaneously consider economic, ecological and social determinants. This requirement is essential when the effects of diversity are addressed in rural areas, where the interdependency of natural, economic and social conditions is critical to determine different developmental patterns. Indeed, the concept of "rural diversity" itself is difficult to quantify, since it could refer to the number of different farms in a given geographical area or to the number of incomes generated within different categories of farms (Heijman et al., 2007). Junge (1994) has proposed a general concept to quantify diversity as the "apportionment of some quantity into a set of well-defined classes". While appealing for its simplicity, this definition does not fully reflect the multifaceted aspect of diversity. Stirling $(1999,2007)$ distinguishes at least three principal subordinated questions related to the quantification of diversity: the first is how many categories should constitute a set (variety); the second is how to characterize the nature or degree of apportionment between categories (balance); the third is what criteria should be used to make "well-defined" distinctions between classes (disparity). This general principle has been adapted to different fields based on specific needs. In economic literature the term diversity often coincides with the term "variety" (Stirling, 1999), since economic diversity is usually considered as the variety of industry, employment or economic activities in the economic system under assessment (Metcalfe and Gibbons, 1988; Metcalfe, 1992; Kirman, 1992; David and Rothwell, 1996). Ecologists on the other hand rely on defined species to resolve the problem of category distinction and therefore also tend to focus more on variety, or number of categories to be measured, and balance to characterize the degree of apportionment between categories. In contrast, conservationists look at disparity to identify well-defined categories including unique features of certain species so as to promote biodiversity. There have been various attempts to integrate different aspects of diversity in order to create a more general index of diversity (Simpson, 1949; Mclntosh, 1967). The term "dual concept diversity" coined by Junge (1994) implements two properties of diversity: variety and balance. A family of indices to quantitatively measure dual concept diversity comes from the field of mathematical ecology (Hill, 1973). These indices include two of the most well-known functions to measure dual concept diversity: the Shannon-Wiener index and the Simpson index. Both indices can be applied to a variety of disciplines in order to "articulate quantities which are directly analogous to variety (i.e. an integer) and balance (i.e. a set of fractions which sum to unity)" (Hill, 1973).

Despite the extensive literature on the quantification of diversity, little attention has been devoted to the development of indices able to capture the degree of diversity of the different components of rural areas. In the following sections an index, the Rural Diversity Index (RDI), is proposed to assess the diversity in rural socio-ecological systems. The proposed index intrinsically considers the effects of presence/absence of different diversity determinants (variety) and their relative weight (balance) and is able to provide a synthetic value referred to the natural, economic and social components of a socio-ecological rural system. The Rural Diversity Index tries specifically to incorporate the assumption that diversity increases resilience when the correct balance between the brittleness/efficiency of low resilience and the stagnation/inefficiency of high resilience is reached (Biggs et al., 2012). The RDI can be then used as a methodological tool to monitor diversity-driven rural development paths and, as stressed above, to assess a key component of SES resilience. In Section $\underline{2}$ an analysis of the various forms of diversity in rural socio-ecological systems, focusing on their implications in terms of development is provided, and the attributes of the components of rural systems (natural, economic, social and institutional), which are relevant in determining the various forms of diversity are outlined. Section 3 presents the Rural Diversity Index (RDI) and its calculation in a Mediterranean rural area.

\section{Rural diversity and development}

Rural diversity has been typically referred to three different aspects: 1) the diversity of agricultural activities within a rural region; 2) diversity of non-agricultural activities of farmers, 3 ) the variety of economic activities within a rural region, whereby agriculture is seen as one of 
the possible economic activities. These diversities are associated with different potential developmental patterns with respect to both production and societal organization systems. However, the rural context is a complex system defined by natural, economic, social and institutional variables, which define altogether the specificity of the rural environment. A first set of characterizing attributes is described in Table 1 (more attributes can be defined). The diversity of each attribute contributes to the whole complexity of the socio-ecological-rural system. In the following sections the fundamental principle of diversity in ecology (i.e. greater biodiversity makes eco-systems more resilient) underlies the RDI development and it is applied to rural systems, in order to test whether increasing diversity in rural areas components would create a greater ability to respond to shocks, thereby becoming more resilient and stable (Kempener et al., 2009).

\begin{tabular}{|c|c|c|c|}
\hline & \multicolumn{3}{|c|}{ Perspectives } \\
\hline Capitals & $\begin{array}{l}\text { Diversity of } \\
\text { agricultural } \\
\text { activities }\end{array}$ & $\begin{array}{l}\text { Diversity of non- } \\
\text { agricultural } \\
\text { activities }\end{array}$ & $\begin{array}{l}\text { Diversity of } \\
\text { economic activities }\end{array}$ \\
\hline Natural & $\begin{array}{l}\text { Cropping mix (Di Falco } \\
\text { and Chavas, 2008; Fraser } \\
\text { et al., 2003; Abson et al., } \\
\text { 2013; Quaranta and } \\
\text { Salvia, 2000; Cabell and } \\
\text { Oelofse, 2012; Ellis, 1999; } \\
\text { Lin, 2011) } \\
\text { Irrigation Water } \\
\text { availability }\end{array}$ & $\begin{array}{l}\text { Availability of } \\
\text { Territorial Natural } \\
\text { Resources (Sachs and } \\
\text { Warner, 1995) }\end{array}$ & $\begin{array}{l}\text { Availability of } \\
\text { Territorial Natural } \\
\text { Resources (Sachs and } \\
\text { Warner, 1995) }\end{array}$ \\
\hline Economic & $\begin{array}{l}\text { Physical size of farms } \\
\text { (Garmestani et al., 2006; } \\
\text { Reidsma and Ewert, 2008) }\end{array}$ & $\begin{array}{l}\text { Farm diversification } \\
\text { (Van der Ploeg et al., } \\
\text { 2000; Kempener et al., } \\
\text { 2009; Marsden, 2009; } \\
\text { Fonte, 2006) }\end{array}$ & $\begin{array}{l}\text { Specialization Index } \\
\text { (Bryden et al., 2011; } \\
\text { Marsden, 2009) } \\
\text { Tourism flow }\end{array}$ \\
\hline Social & $\begin{array}{l}\text { Educational level } \\
\text { Wage workers }\end{array}$ & $\begin{array}{l}\text { Family members off- } \\
\text { farm job }\end{array}$ & Employment profile \\
\hline Institutional & Land tenure & $\begin{array}{l}\text { Farm participation in } \\
\text { cooperatives, } \\
\text { associations, etc. }\end{array}$ & Land protection \\
\hline
\end{tabular}

Tab 1. Perspectives and attributes. Source: own elaboration.

\subsection{Diversity of agricultural activities}

The first interpretation of rural diversity argues that a greater variety of agricultural activities promotes stability and better protects rural areas from economic stresses. Di Falco and Chavas (2008) argue that crop diversity will also prove important in protecting against potential future climatic changes. Wider genetic variety may be better able to respond to shocks such as changes to rainfall or temperatures and might prevent the risk of decreasing yields in the long term. Over the last sixty years the global agri-food industry has been moving towards an increasingly specialised model with large, capital intensive farms dominating the industry (Horlings and Marsden, 2011). This specialisation came in response to the drive for efficiency, increased yields, economies of scale and reduced costs of production. Evidence suggests that the degree of specialisation in the agricultural sector is resulting in less resilient farms (Fraser et al., 2003) which are more vulnerable to income volatility (Abson et al., 2013). As a result there may have to be a trade-off between high yields and economic efficiency and resilience in modern agricultural systems.

A good example of the benefits of diversity in agricultural practices comes from the lessons already learnt from highly specialized agricultural production, agricultural policies which heavily promote intensive production, the re-organization of primary sector production driven by technological progress and revenue shortfalls compared with other economic sectors, the globalization of markets and the need to stay competitive. Despite the high-yields and 
economic efficiency of this production system, mono-cropping creates unsustainable pressure on eco-systems in the form of soil erosion and nutrient imbalances, increased fertilizer and pesticide use leading to an increased risk of pollution of water tables, loss of biological diversity, atmospheric degradation and increased risk of plant disease epidemics due the concentrated presence of a single cultivar (Quaranta and Salvia, 2000). In contrast, diversity of agricultural activities "dilutes" the risk for farmers as it provides different sources of income with differing risks. For example, rural areas practicing mono-cropping would be particularly vulnerable in a bad year (adverse weather conditions or exceptional spread of disease/s), whereas areas with diversified agricultural activities would likely have alternative sources of income under similar unfavourable conditions (Cabell and Oelofse, 2012). Furthermore, diversity of agricultural activities can also improve the efficiency of labour utilization by generating alternative sources of income in off-peak periods (Ellis, 1999). In this case, the specific attributes for such diversity, based on Table 1, refer to the cropping mix and irrigation water availability for the natural component, to farm size for the economic component, to educational level and wage workers availability for the social component. The institutional component mainly refers to the type of property (land tenure).

Studies on crop diversification (cropping mix in Table 1) have attempted to show the positive effects of crop diversity on ecologic resilience. However, crop diversification has proved difficult to implement for two main reasons. Firstly, economic incentives often favour the production of few, specific crops; secondly, farmers are generally reluctant to abandon specialized monoculture cropping systems that usually guarantee higher incomes (Lin, 2011).

The presence of farms with irrigation and without irrigation (Irrigation Water availability in Table 1) in rural areas guarantees a greater variability of cropping systems, which require different levels of specialization and knowledge. In non-irrigated farming systems this knowledge is often associated with traditional agricultural practices and local know-how.

Size diversity is critical for firms in order to remain resilient to fluctuating markets and economic changes (Garmestani et al., 2006). Greater functional diversity of firms corresponds to their greater capability to maintain steady employment. Farm size, together with land use types and intensity, is one of the factors taken in consideration by Reidsma and Ewert (2008) in developing their Regional farm diversity index in the study of vulnerability of food production to climate change. The use of regional farm diversity suggests that the diversity in farm size and intensity, particularly high in Mediterranean regions, reduces vulnerability of regional wheat yields to climate variability.

The presence of different levels of education (Educational level in Table 1) in the population allows rural areas to meet the needs of various types of employment.

The presence of farms with waged and non-waged workers reduces the inherent drawbacks associated with having either an exclusively waged or exclusively non-waged workforce. The mix of waged and non-waged labour also reduces the need for farms to use an external workforce, thus avoiding problems related to fluctuations of labour costs and availability. This is particularly important to family-run farms for which the flexibility in the choice of cropping systems relies on the valorisation of family labour. With respect to land tenure, farms using rented land can respond to and more easily adapt scale of production to fluctuating market conditions and therefore maintain competitiveness. On the other hand, farms with owned land tend to have higher investment rates, which ultimately increase the land value and the income for the farm under stable market conditions.

\subsection{Diversity of non-agricultural activities}

In the second interpretation of rural diversity the central consideration is the innovative use of farmers' resources, through such activities as agri-tourism enterprises, organic farming, nature and landscape management and high-quality production, in an attempt to overcome the continuing cost of production/price squeeze which is characterising modern 'productivist' agriculture (Van der Ploeg et al., 2000). As has emerged from the EU IMPACT project (http://www.rural-impact.net), the paradigm of modernization that once dominated policy, practice and theory is being replaced by a new rural development paradigm where rural 
development is considered as a multi-level, multi-actor and multi-facetted process rooted in historical traditions. The new expectations that society has of rural areas, along with the need to react to an ever smaller economic base has pushed farmers to innovate with new quality products, services and efficiency savings in an attempt to drive down production costs. Rural development therefore is largely a self-driven process in which agriculture will continue to play a key role, although the exact nature of the role may be subject to change.

In the second interpretation of rural diversity, it is argued, thus, that farmers practising one or various non-agricultural activities are more flexible to changes. In times of agricultural difficulties, these activities provide alternative sources of income and, ultimately, contribute to the performance of the rural region as a whole. The term "diversification" is commonly used in this context and is defined as "farmers enhancing their household income from sources other than conventional farming production through diversifying their business activities" (Kempener et al., 2009). Examples of this type of diversification include forms of entrepreneurial activities, such as agro-tourism, recreational activities or retailing. Diversification has already proved popular amongst farmers. Recent studies estimate that in Europe at least half of farmers are actively engaged in more than one rural development practice (Marsden, 2009). It has been reported that in some labour markets diversification can cause disparities among farmers with different levels of income. This occurs because the better-off are able to diversify more effectively than poorer farmers, who necessarily can only rely on part-time and unskilled work, limited organizational tools and have low investment potential. This is usually the case for developing countries (Ellis, 1999) where the role of migration and reliance on remittances is, however, to be considered important as they provide a form of income diversification for households and represent an important survival strategy for many poor rural households. Another risk associated with the development of this type of rural diversity is the need for additional specialization and labour skills. The expansion of local agro-food economies of traditional products to distant and larger mass markets requires a standardization of the production techniques which has to comply with food hygiene, health and safety regulations as well as certification systems (Protected Designation of Origin (PDO), Protected Geographical Indication (PGI) or Traditional Speciality Guaranteed (TSG). This may call for the need to involve experts to work in collaboration with local producers. Nevertheless, there is a risk that such collaboration on certification processes leads to negative social effects if overall control is not given to local actors. In this case local producer knowledge may become expropriated rather than integrated with scientific knowledge and the resulting valorisation of local products may benefit external actors rather than local actors. For example, in the Mesenikola region of Greece, local wine producers were unable to profit from the emergence of a quality-certified wine production, which benefited instead only non-local entrepreneurs who transferred their business into the Protected Designation of Origin area (Fonte, 2006). In other cases, local producers, especially poor farming families, may lack the knowledge or resources to navigate the bureaucracy surrounding the certification procedure for hygiene norms, health and safety requirements and regulations for authentic production techniques. Even with the support from Non-Governmental Organizations or local knowledge sharing initiatives, small local producers often cannot cover the costs of the certification systems and, as a result, are driven away from the markets (Fonte, 2006).

Availability of territorial natural resources, i.e. the proportion of the territory's surface area covered by woods, plains, hilly land, surface water bodies, accounts for the diversity of natural resources, which is essential for the diversification of economic activities. However, some instances can be found of development (productive and diverse economic activities) in regions that face a low diversity of natural resources, as Singapore (Sachs and Warner, 1995).

With respect to farm diversification, the presence of in-farm and off-farm product sales makes rural areas less vulnerable to fluctuations of the markets as well as less dependent on rural tourism fluxes.

An additional level of diversification is attributable to the composition of rural family employment, i.e. the presence of family members employed solely in agriculture or also working in other sectors. In the first case there is greater supervision of farming activities, particularly those which require the constant presence of a labour force (e.g. animal husbandry). In the second 
case job diversification within the family may bring other sources of income, which are not dependent on agricultural markets. Furthermore, off-farm jobs could strengthen the innovation rate of the farm through the transfer of know-how, new forms of organization and technologies acquired outside by family members. Finally, the presence of farms that are active in associations and co-operatives and farms which are not guarantees more diversified decisionmaking processes in the territory.

\subsection{Diversity of economic activities}

For the third interpretation of rural diversity the focus is on the economic diversification of rural areas. Rural areas are today facing exciting new development opportunities thanks to the spread of globalization and greatly increased mobility and accessibility. Natural capital, landscapes, intact natural environments and local productions all represent the type of public or quasi public goods which can be used to diversify and strengthen rural economies and maintain the social, economic and cultural services needed to keep local resident population stable. We can hypothesize that a broad range of economic activities within a rural system, as a whole, will better protect the system from stress and disturbances. For example, poor performance in the agricultural sector would leave rural areas strictly dependant on agriculture especially vulnerable. Alternatively, rural areas with diversified economic activities are more resilient to shocks or fluctuations of the system. The TOPMARD project, for example, through the development of an interdisciplinary-based model of agriculture and rural development and adopting a system dynamics approach, analysed the dynamics and interconnectedness of the agronomic, ecological, economic and social dimensions of rural regions (Bryden et al., 2011). However, increased residential, touristic and labour migration as a result of economic expansion in rural areas could pose new threats to rural social-ecological systems (Marsden, 2009). Particularly in those rural areas close to large urban centres, the flow of people and capital to the country can cause both identity lost and unsustainable pressure on natural resources, reduction of utilized agricultural surface and increased soil sealing, as well as inflating house prices as the rural residential housing market becomes more exclusive due to the purchase of land to build second homes/retirement homes by urban and ex-urban residents (Marsden, 2009).

A broad range of economic activities within a rural system will better protect the system from stress and disturbances. Various typologies of tourism in the territory allows this industry to better react and adapt to fluctuations in the market and possible future dips in demand of one or another particular type of tourism. Similarly, the presence of people with different employment profiles allows the rural area to easily adapt and counterbalance shocks in different labour markets. Finally, the presence of protected (parks) and non-protected land in the territory guarantees fewer limitations to land-use, whilst increasing awareness of the culture of "protection".

\subsection{Linking perspectives, attributes and indicators}

Table 2 reports the set of the selected indicators according to perspectives and attributes. The way the RDI was constructed means the resulting value is influenced neither by the number nor typology of indicators, therefore the list of indicators is a first attempt made to operationalise attributes and it is based also on the generally available data from official sources.

Quantitative statistical data from official sources can be integrated with qualitative data collected from extensive local stakeholder interviews and workshops, for example. The quantitative and qualitative approaches to data collection, of course, can provide for a much deeper and more nuanced understanding of the changes that take place within SES than statistics alone could supply.

A trade-off should be made between the cost, both in terms of economic resources and time, associated with data quality and quantity, and the objective of the analysis. When the objective of analysis is the dynamics of a socio-ecological system along a wide spatial and temporal scale an indicator such as the RDI fed only with statistical data could be sufficient. 


\begin{tabular}{|c|c|c|c|}
\hline $\begin{array}{l}\text { PERSPEC } \\
\text { TIVES }\end{array}$ & ATTRIBUTE & ACRONYM & INDICATOR \\
\hline \multirow{6}{*}{ 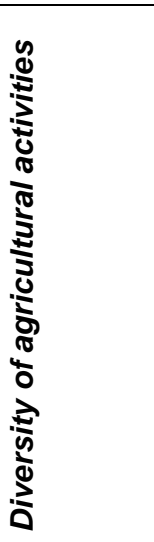 } & Cropping mix & CM & $\begin{array}{l}\text { proportion of arable land; permanent crops; pasture on } \\
\text { total agricultural land }\end{array}$ \\
\hline & Irrigation water availability & IA & $\begin{array}{l}\text { proportion of irrigated and unirrigated farms on total } \\
\text { farms }\end{array}$ \\
\hline & Physical size of the farms & PS & $\begin{array}{l}\text { proportion of number of farms belonging to different } \\
\text { Utilized Agricultural Area (UAA) classes on total UAA }\end{array}$ \\
\hline & Educational level & EL & $\begin{array}{l}\text { proportion of various educational qualifications on total } \\
\text { educated population }\end{array}$ \\
\hline & Wage workers & WW & proportion of wage workers on total agricultural labor \\
\hline & Land tenure & LT & $\begin{array}{l}\text { proportion of the hired and property land on total farm } \\
\text { land }\end{array}$ \\
\hline \multirow{4}{*}{ 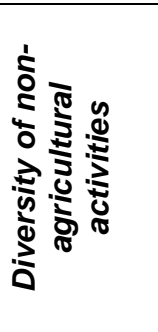 } & $\begin{array}{l}\text { Availability of Territorial } \\
\text { Natural Resources }\end{array}$ & TNR & $\begin{array}{l}\text { proportion of forest surface and not on the total } \\
\text { municipality surface }\end{array}$ \\
\hline & Farm diversification & FD & $\begin{array}{l}\text { proportion of farm with alternative activities (agro- } \\
\text { tourism, energy, etc.) and farms without on total farms }\end{array}$ \\
\hline & Family members off-farm job & OF & $\begin{array}{l}\text { proportion of farms with family members having off- } \\
\text { farm job and farms without on the total number of } \\
\text { farms }\end{array}$ \\
\hline & $\begin{array}{l}\text { Farm participation in coop, } \\
\text { association etc }\end{array}$ & FP & $\begin{array}{l}\text { proportion of farm associated and farms not on } \\
\text { the total number of farms }\end{array}$ \\
\hline \multirow{4}{*}{ 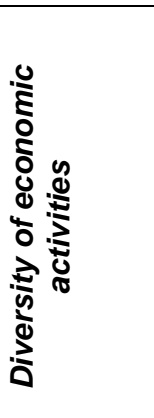 } & Specialization index & SI & $\begin{array}{l}\text { proportion of Added Value (AV) of each sector on } \\
\text { the total AV }\end{array}$ \\
\hline & Tourism flow & TF & $\begin{array}{l}\text { proportion of beds per each touristic typology (hotel, } \\
\text { agro-tourism etc.) on total beds; proportion of presence } \\
\text { per accommodation typology (hotel, agro-tourism etc.) } \\
\text { on total presence. }\end{array}$ \\
\hline & Employment profile & EP & proportion of different typologies on total employed \\
\hline & Land protection & LP & $\begin{array}{l}\text { proportion of protected and not protected land on total } \\
\text { municipality surface }\end{array}$ \\
\hline
\end{tabular}

Tab 2. Selected indicators to operationalise attributes. Source: Authors elaboration.

\section{Measuring diversity: the Rural Diversity Index - RDI}

The need for a synthetic indicator, able to simultaneously take into consideration all the drivers of diversity in rural socio-ecological systems, led to the definition, development and application of the Rural Diversity Index (RDI). The RDI is an index that measures the diversity of rural socio-ecological systems on the basis of the three dominant perspectives of rural diversity: 1) agricultural diversification; 2) non-agricultural diversification; 3) diversification of the rural economy as a whole, and four capitals: 1) natural; 2) economic; 3) social and 4) institutional, which make up rural socio ecological systems.

The RDI is an attempt to produce a tailor-made index, able to effectively measure diversity exclusively in the context of rural socio-ecological systems. The index has been designed to be user-friendly, it is based on relatively straightforward calculations and ranges between 0 and 1 , where 1 corresponds to maximum diversity and 0 corresponds to the lowest degree of diversity. The RDI aims at providing a general picture of the current state, and changes over time, of diversity within rural areas. 
The $R D I$ can be defined as follows:

$$
R D I=\sum_{j=1}^{v} P_{j} / v \quad R D I, P_{j}=[0,1]
$$

where

$v=$ indicator considered to describe diversity attribute

$P_{j}=\prod_{i=1}^{n}\left[\left(f_{i}\right)^{1 / n}\right] * n$

$P_{j}$ represents the geometric mean of frequency classes $\left(f_{i}\right)$ multiplied by $n$ to constrain RDI between 0 and 1 .

$n=$ number of classes

$f_{i}=a_{i} / m$

$a_{i}=$ value of indicator for each class considered

$m=\sum_{i=1}^{n} a_{i}$

An RDI value of 1 would indicate an ideal situation where all possible values of each indicator have the same weight. In addition to its simplicity and immediacy, the RDI is also highly flexible and can be used in different rural systems regardless of the number and nature of their attributes and related indicators ${ }^{3}$. This is particularly useful when the available indicators cannot be easily compared due to different units of measurement (for example, farm size and level of education of family members).

This index can:

1) Process indicators with differing class numbers.

2) Assess indicators from different time scales.

In order to operationalise the RDI the following steps are needed:

- Select a number of indicators/variables relevant to identify socio-ecological diversity in the SES under study, according to the perspectives under which diversity has to be measured and the relative attributes (Table 2)

- Define the classes for each indicator/variable.

The first criterion to define number of classes for each indicator is based on the functionality of each class. For example, the division of farm classes can be based on the organizational and managerial characteristics related to farm size or the role these farms plays within a rural area. The second criterion to define the number of classes is to avoid excessive fragmentation of classes. This criterion is to prevent empty and/or redundant classes which could turn out a lesser degree of diversity. This is caused by the fact that the product

\footnotetext{
${ }^{3}$ The way the index is constructed allows for the easy introduction of different weights for single attributes (indicators) although this operation could introduce arbitrary elements into the analysis. For this first development of the RDI no weights were applied to any attribute (indicator).
} 
operator calculates all empty classes as having a value of nil, in keeping with a principle of caution based on which the absence of possible values for indicators indicates a reduced level of diversity rather than a specialization.

- Calculate the frequency of each class and apply the formula.

\subsection{Calculation of the RDI}

The RDI has been first empirically tested in the Alento River basin, Southern Italy. This area has been proved to be a socio-ecological system within the EU funded LEDDRA project ${ }^{4}$ as an area in which both physical and socio-economic components are integrated and the use of resources is shared. This area has an extension of $\sim 55,000$ hectares and a population of 44,000 inhabitants.

The RDI was calculated for each municipality belonging to the SES for the years 1970 to 2000 , thereby taking into account the period of greatest socio-economic change for the area (economic boom, industrialization, mass out migration, intensive farming practices etc.). Municipality represents the minimum unit where official data are collected.

An example is provided to illustrate the steps needed to calculate RDI (Table 3). It refers to a single year (2000) and one municipality.

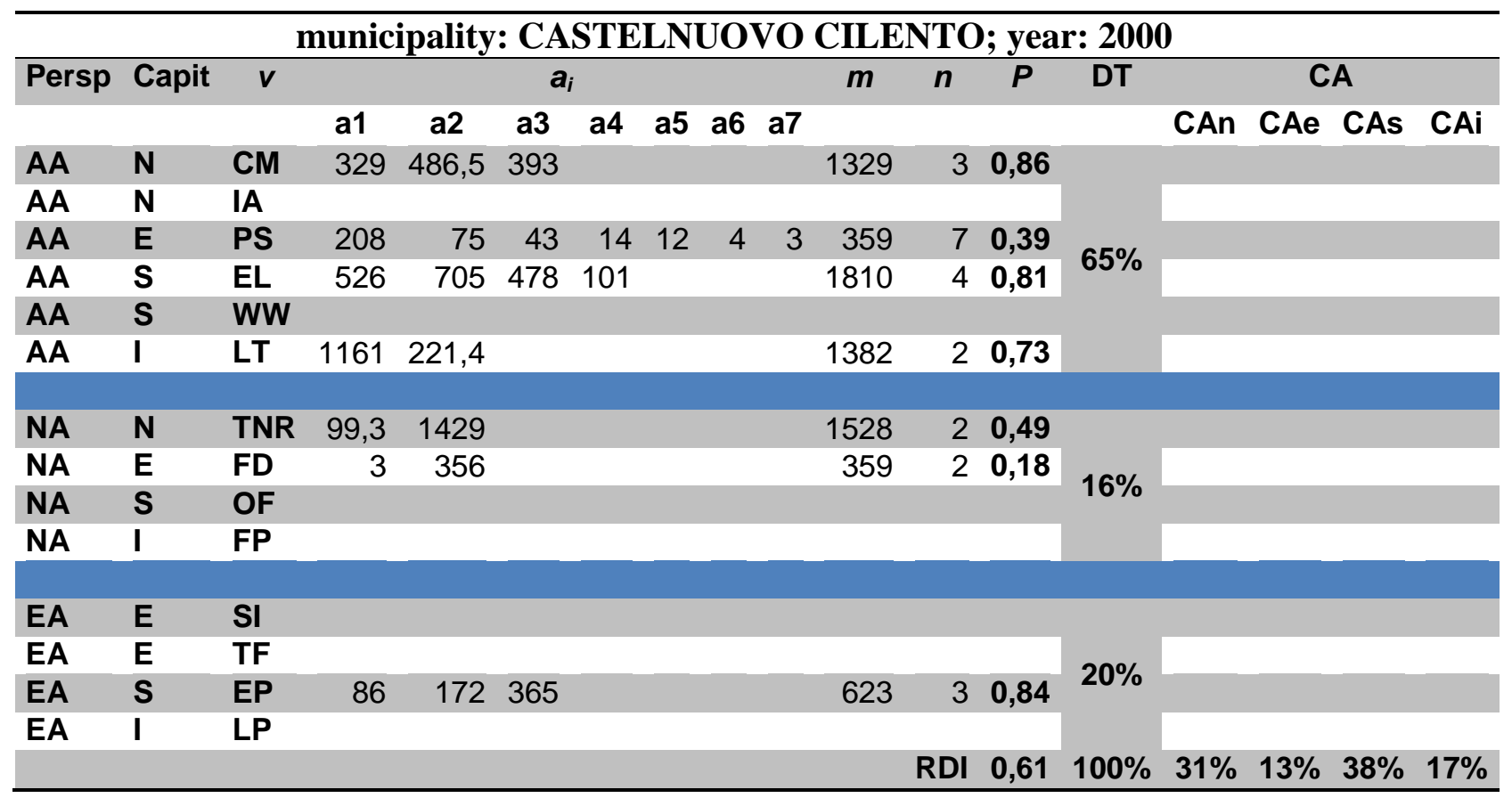

\section{LEGEND}

$\begin{array}{llll}\text { Persp } & \text { Perspectives } & \text { Capit } & \text { Capital } \\ \text { AA } & \text { Diversity of agricultural activities } & \text { N } & \text { Natural } \\ \text { NA } & \text { Diversity of non-agricultural activities } & \text { E } & \text { Economic } \\ \text { EA } & \text { Diversity of economic activities } & \text { S } & \begin{array}{l}\text { Social } \\ \text { Institutional }\end{array} \\ & & \text { I } & \\ \text { CM } & \text { cropping mix } & \text { LT } & \text { Land tenure } \\ \text { a1 } & \text { arable land (hectares) } & \text { a1 } & \text { Owned } \\ \text { a2 } & \text { permanent crops (hectares) } & \text { a2 } & \text { Others } \\ \text { a3 } & \text { pasture (hectares) } & \text { m } & \text { Total hectares }\end{array}$

\footnotetext{
${ }^{4}$ LEDDRA project -FP7-ENV-2009-1 Collaborative project (SICA, Grant Agreement No. 243857. LEDDRA analyses the fit of responses to land degradation and desertification in ten socio-ecological systems from EU, China and Morocco.
} 


\begin{tabular}{|c|c|c|c|}
\hline $\mathrm{m}$ & total agricultural land & & \\
\hline PS & Physical size of the farms & TNR & $\begin{array}{l}\text { Availability of Territorial Natural } \\
\text { Resources }\end{array}$ \\
\hline a1 & farms without agricultural land & a1 & Woods \\
\hline a2 & farms $1-2$ hectares & a2 & Cultivated land \\
\hline a3 & farms 2-5hectares & $\mathrm{m}$ & Total territorial surface \\
\hline a4 & farms $5-10$ hectares & & \\
\hline a5 & farms $10-20$ hectares & FD & $\begin{array}{l}\text { Farm diversification } \\
\text { farms with agri-tourism }\end{array}$ \\
\hline a6 & farms $20-50$ hectares & a1 & $\begin{array}{l}\text { structures } \\
\text { farms without additional }\end{array}$ \\
\hline a7 & $\begin{array}{l}\text { farms over } 50 \text { hectares } \\
\text { total }\end{array}$ & a2 & activities \\
\hline $\mathrm{m}$ & farms & $\mathrm{m}$ & total farms \\
\hline EL & Educational level & & \\
\hline a1 & people completing elementary school & EP & Employment Profile \\
\hline a2 & people completing middle school & a1 & Agriculture \\
\hline a3 & people completing high school & a2 & Industry \\
\hline a4 & people with a university degree & a3 & Other activities \\
\hline m & total with educational qualification & $\mathrm{m}$ & Total employed \\
\hline \multirow[t]{4}{*}{ DT } & $\begin{array}{l}\text { Contribution of Diversification strategies to } \\
\text { RDI - \% }\end{array}$ & $\begin{array}{l}\text { CA } \\
\text { CAn }\end{array}$ & $\begin{array}{l}\text { Capital contribution on RDI \% } \\
\text { Natural capital contribution to } \\
\text { RDI }\end{array}$ \\
\hline & & $\mathrm{CAe}$ & $\begin{array}{l}\text { Economic capital contribution to } \\
\text { RDI }\end{array}$ \\
\hline & & CAs & Social capital contribution to RDI \\
\hline & & $\mathrm{CAi}$ & $\begin{array}{l}\text { Institutional capital contribution } \\
\text { to RDI }\end{array}$ \\
\hline
\end{tabular}

Tab 3. Calculation of the RDI

According to data availability (official sources) seven attributes (tables 3) out of 14 (Table 2) have been calculated. Specifically cropping mix, as proportion of arable land; permanent crops and pasture on total agricultural land; Physical size of the farms, as proportion of number of farms belonging to different Utilized Agricultural Area (UAA) classes on total UAA; Education Level, as proportion of population with different educational level on total population with degree; Land Tenure as proportion of the hired and property land on total farm land. All these indicators specify attributes relative to the perspective "Diversity of agricultural activities". Availability of Territorial Natural Resources, expressed as proportion of forest surface and not on the total municipality surface and Farm Diversification, as proportion of farm with alternative activities (agro-tourism, Energy, etc) and farms without on total farms have been calculated for the "Diversity of non-agricultural activities" perspective. Finally Availability of Territorial Natural Resources, as described before, and Employment, i.e. the proportion of different typology on total employed has been referred to "Diversity of economic activities" perspective. Table 3 shows the necessary information to calculate the RDI. The $v$ column shows the attributes (with the relative indicators) effectively calculated based on data availability for that year and municipality. The next column shows the absolute values of the different indicators in each class identified $\left(a_{i}\right)$ whilst the total value is shown in the column marked $m$. These information are sufficient to calculate the Product Operator relative to each attribute $(P)$. The sum of the Product Operators divided by the number of attributes calculated $(v)$ gives the value of the RDI.

The RDI can be used to carry out a more in depth analysis by taking into account both the dynamics of the three diversity perspectives and single capitals (Table 1) within the SES. In 
the first case, development trajectories can be identified by assessing the effect of differentiation and/or diversification in the agricultural sector or in the social-economic context of the SES (column DT in table 3). An analysis of the four capitals, on the other hand, allows us to identify processes which may simplify or increase the complexity of the rural economy (column CA in table 3).

\subsection{Linking RDI with resilience and economic performance}

The values of the RDI for each municipality in 1970 and 2000 were compared with the average RDI values within the SES for each year taken into consideration. The distribution of the RDIs for the municipalities within the four quadrants of Figure 1 reflects their position with respect to the mean in both considered periods. The intersection of the axes represents the average value of the SES in both periods analyzed (1970-2000).

The top right quadrant can be defined as Highly-Stable and identifies the municipalities which have a higher RDI than average for both periods. The bottom right quadrant can be defined as Decreasing and includes the municipalities where RDI is higher than average for 1970 but register a RDI below the SES average for the year 2000. The bottom left quadrant, Low-Stable, includes the municipalities where diversity was below the average values of the SES for both 1970 and 2000. The top left quadrant, Increasing, identifies municipalities which registered below average RDI values compared to those of the SES in 1970 but registered an increase in RDI values compared to the SES average values in 2000.

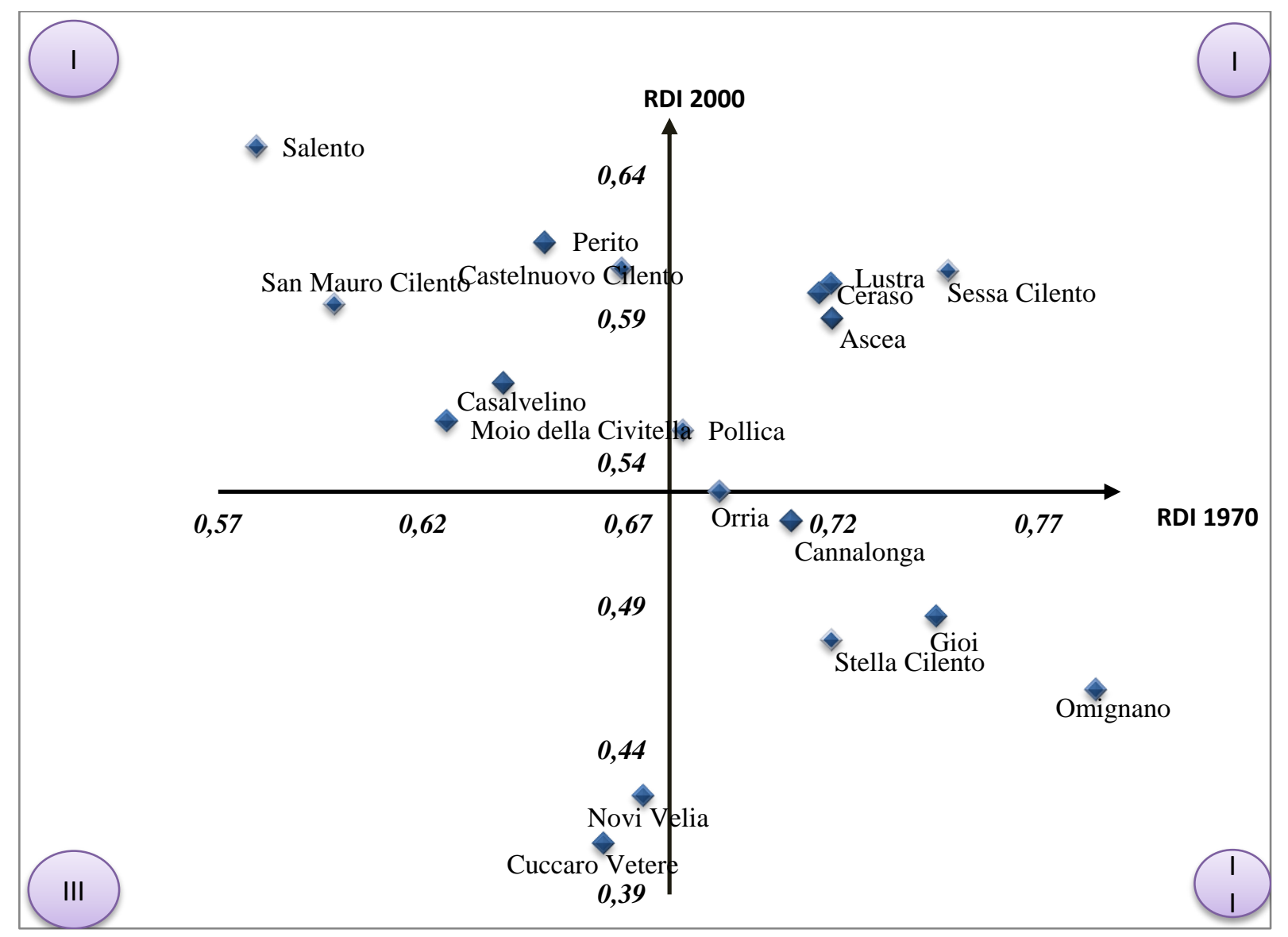

Fig 1. Rural Diversity Index (RDI) 1970 and 2000.

These values of RDI therefore identify four trajectories within the Alento rural SES which express four different strategies of adaptation and/or transformation in respect to the exogenous and endogenous dynamics that have characterised and shaped the SES over the last 50 years. The municipalities in the top right quadrant, which maintain constant overall diversity in the time frame considered, show a part of the SES which has "resisted" the shock wave brought about by the progressive simplification/homogenisation of cropping systems in farming over the last 
fifty years, both through farm diversification and the maintenance of a diversified mix of crops, and has preserved a balanced combination among the different productive sectors.

The top left quadrant, on the other hand, shows the territories which have reacted to the changes underway by introducing elements of diversity into their natural, economic, social and institutional matrices. This quadrant is, in fact, home to those municipalities, such as San Mauro Cilento, which have shown a good degree of farm diversification, diversified agricultural activities and especially good management practices. Also in terms of social and institutional capital there has been a strengthening of intra and extra community relations and a greater degree of collaboration and cooperation between private and institutional actors.

The bottom quadrants show territorial strategies with low diversity values (bottom left) and simplification/homogenisation of socio-economic, institutional and natural fabric (bottom right). In the first case there are the municipalities which are characterised, especially under the profile of natural capital, by their uniformity due to the predominance of woods which have shown a high degree of persistence over the last fifty years. Finally, the bottom-right quadrant shows the communities whose reaction to external pressures has been the simplification of cropping and productive systems and, in some cases, the de-activation of economic activities entirely and dramatic processes of depopulation (for example Stella Cilento). Although an in-depth examination of the relationship between the values indicated by the RDI and the resilience is not the direct aim of the current analysis, it is worth highlighting how the construction of the RDI allows the verification of what Wilson (2012) identified as a possible measure of community resilience, or rather the balance between the three different types of capitals which make up an SES (natural, economic and social capital, including also institutional capital in the component social capital). Rural resilience, as outlined above, can be defined as the ability of a rural territory to adapt, maintain or re-configure the balance between its environmental, economic and social components and functions following shocks to the system (Heijman et al., 2007).

Socio-ecological resilience is therefore predicated on an understanding that a socio-ecological system, such as a rural territory, for example, cannot be considered in isolation but rather as a complex interplay of interdependent components and processes acting and operating across multiple spatial and temporal scales where change in one component or process can lead to change in others and ultimately to change in the resilience of the SES. Maintaining such resilience in a rural SES is vital for its long-term survival.

The territorial unit of Alento River Basin is characterized by uneven levels of socio-economic development. The variation in per-capita disposable income amongst the 18 different municipalities in the territory highlights the diverse economic performance within the territory.

As such the area is well suited to show another intrinsic possibility of the construction of the RDI, or rather its capacity to verify to what degree the strategies of diversification adopted in a rural context are connected to its economic performance. In other words a relationship between diversity (of rural strategies) and economic development can be established.

In order to apply the RDI, indicators capable of measuring the various attributes of diversity and, thus, the three perspectives, as described in section two and above, were identified. Figure 2 match the values of RDI for the year 2000 with per-capita disposable income (DI).

The results revealed a positive relationship between RDI and per-capita disposable income (Figure 2). As shown by the Figure 2, municipalities that show a higher RDI reveal also a higher per-capita disposable income. An in-depth analysis of the values of the RDI could easily identify to what degree the three diversification strategies adopted by the different territories have lead to different economic performances. 


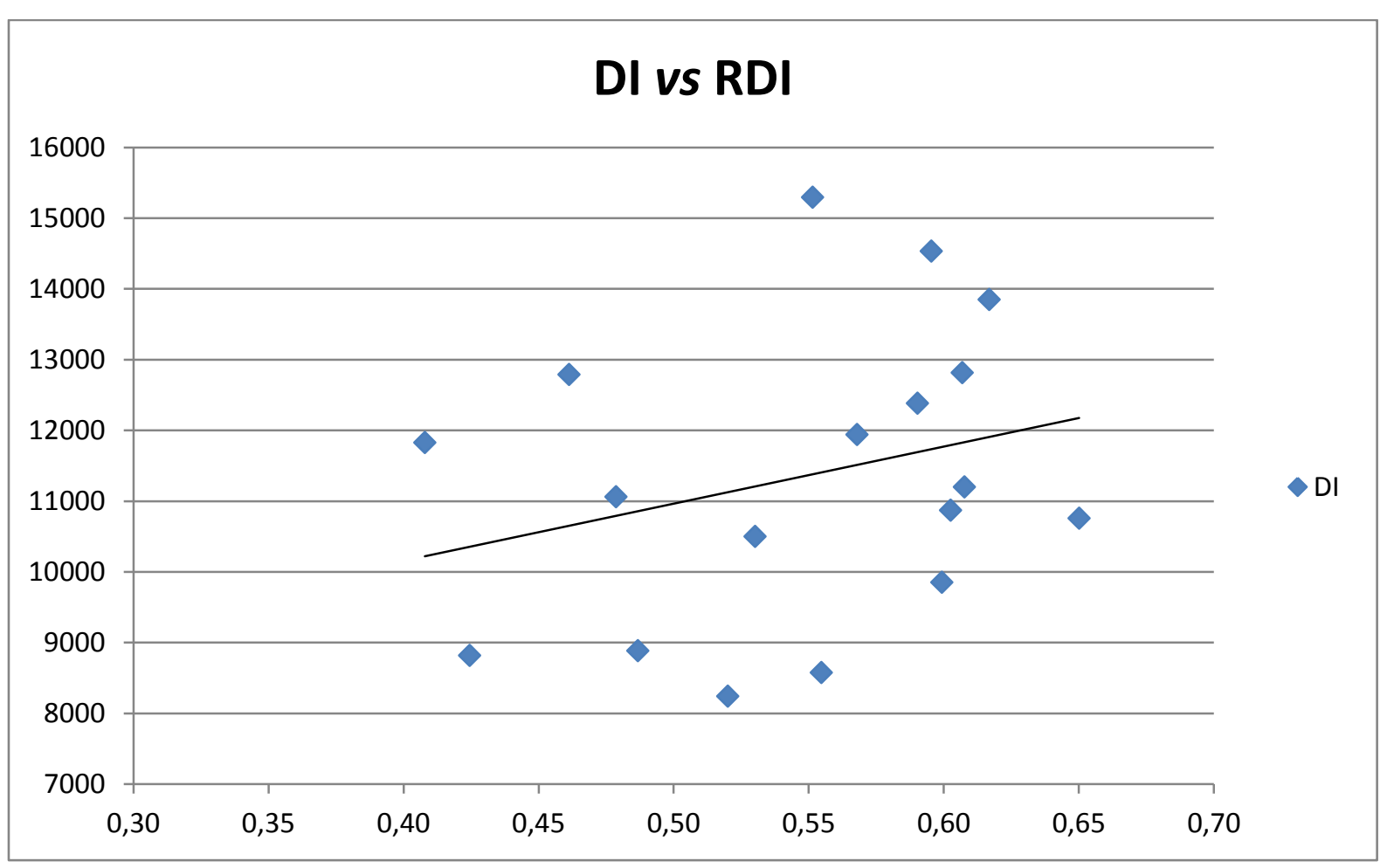

Fig 2. Disposable Income (DI) and Rural Diversity Index (RDI) 2000.

\section{Conclusions}

An analytical tool for measuring diversity of rural socio-ecological systems was defined. The Rural Diversity Index (RDI) takes into account the different definitions of diversity and the capitals specific to given rural area contexts. The RDI does, however, have the advantage that it can be built with data that can be easily sourced from official statistics. The index has been calculated in a rural Mediterranean area showing the ability to capture resilience patterns and socio-economic performances in rural areas. The RDI is highly flexible and able to evaluate data with different units, which is essential in measuring diversity in complex contexts such as rural socio-ecological systems. In this respect, currently available ecological and socioeconomic indices are less effective at measuring diversity in rural SES as compared to the RDI because these indices measure specific single aspects of diversity depending on the context in which they are applied (biodiversity, economy etc.). In contrast, the RDI is able to provide an integrated assessment of various types of diversity in the context of rural socio-ecological systems. The index also has another important application beyond measuring the diversity of rural areas which is to assist policymakers in weighing optimal policies in relation to their capacity to influence and/or change the dynamics of diversity. Since the index allows to identify the various characteristics of single components of the RDI, it may represent an important tool for policymakers who wish to assess where and how to best intervene in order to facilitate development in a given territory.

This work is a first step in the direction to better understanding the link between diversity in a socio-ecological systems and its resilience. The RDI helps analysis to what degree a territory is able to diversify all its components (natural, economic, social and institutional) in a balanced manner. The index also opens up further questions in the direction of investigating in greater detail to what degree the different strategies of diversification in place in rural territories, or lack thereof, impact economic performance and rural development patterns.

\section{Acknowledgements}

Work partially funded by LEDDRA project - FP7-ENV-2009-1 Collaborative project (SICA, Grant Agreement No. 243857). 
[1] Abson, D. J., Fraser, E. D. G. \& Benton, T. G. (2013). Landscape diversity and the resilience of agricultural returns: a portfolio analysis of land use patterns and economic returns from lowland agriculture. Agriculture \& Food Security 2(2), 1-15. Doi: 10.1186/20487010-2-2.

[2] Ambrosio-Albalá, M., Bastiaensen, J. (2010). The New Territorial Paradigm of Rural Development: Theoretical Foundations From Systems and Institutional Theories. Discussion Paper 2010/02, IOB Antwerp University.

[3] Anderies, J. M. (2006). Robustness, institutions, and large-scale change in socialecological systems: the Hohokam of the Phoenix Basin. Journal of Institutional Economics, 2(2), 133-155. Doi: 10.1017/S1744137406000312.

[4] Anderies, J. M., Walker, B. H. \& Kinzig, A. P. (2006). Fifteen weddings and a funeral: case studies and resilience-based management. Ecology and Society, 11(1), 21. http://www.ecologyandsociety.org/vol11/iss1/art21/.

[5] Anderies, J. M., Rodriguez, A. A., Janssen, M. A. \& Cifdaloz, O. (2007). Panaceas, uncertainty, and the robust control framework in sustainability science. Proceedings of the National Academy of Sciences of the United States of America, 104 (39), 15194-15199.

[6] Apeldoorn, D. F. v.d, Kok, K., Sonnevald, M. P. W. \& Veldkamp, T. A. (2011). Panarchy Rules: Rethinking Resilience of Agro-systems, Evidence from Dutch Diary-Farming. Ecology and Society 16 (1): 39. http://www.ecologyandsociety.org/vol16/iss1/art39.

[7] Biggs, R., Schluter, M., Biggs, D., Bohensky, E. L., BurnSilver, S., Cundill, G., Dakos, V., Daw, T. M., Evans, L. S., Kotschy, K., Leitch, A. M., Meek, C., Quinlan, A., RaudseppHearne, C., Robards, M. D., Schoon, M. L., Schultz, L. \& West, P. C. (2012). Toward Principles for Enhancing the Resilience of Ecosystem Services. Annual Review of Environment and Resources, 37, 421-448. Doi: 10.1146/annurev-environ-051211-123836.

[8] Bryden, J. M., Efstratoglou, S., Ferenczi, T., Knickel, K., Johnson, T., Refsgaard, K., Thomson, K. J., eds. (2011). Towards Sustainable Rural Regions in Europe, Exploring Inter-Relationships Between Rural Policies, Farming, Environment, Demographics, Regional Economies and Quality of Life Using System Dynamics. London: Routledge.

[9] Cabell, J. F. \& Oelofse, M. (2012). An indicator framework for assessing agroecosystem resilience. Ecology and Society 17(1): 18. Doi: 10.5751/ES-04666-170118.

[10] Chapin III, F. S., Walker, B. H., Hobbs, R. J., Hooper, D. U., Lawton, J. H., Sala, O. E. \& Tilman, D. (1997). Biotic control over the functioning of ecosystems. Science, 277(5325), 500-504. Doi: 10.1126/science.277.5325.500.

[11] Chapin, F. S., Kofinas G. P., Folke, C., eds. (2009). Principles of Ecosystem Stewardship: Resilience-Based Natural Resources Management in a Changing World. New York: Springer.

[12] Chavas J. P. \& Di Falco S. (2012). On the productive value of crop biodiversity: evidence from the highlands of Ethiopia. Land Economics 88(1), 58-74.

[13] David, P. \& Rothwell, G. (1996). Standardization, Diversity and Learning: strategies for the co evolution of technology and industrial capacity. International Journal of Industrial Organization, 14(2), 181-201. Doi: 10.1016/0167-7187(95)00475-0.

[14] Di Falco, S., Chavas, J. P. (2008). Rainfall shocks, resilience, and the effects of crop biodiversity on agroecosystem productivity. Land Economics 84(1):83-96.

[15] Ellis, F. (1999). Rural Livelihood diversity in developing countries: evidence and policy implications. Natural Resource Perspectives, 40. Retrieved from http://www.odi.org.uk/resources/download/2112.pdf. 
[16] Elmqvist, T., Folke, C., Nystrom, M., Peterson, G. D., Bengtsson, J., Walker, B. H. \& Norberg, J. (2003). Response diversity and ecosystem resilience. Frontiers in Ecology and the Environment, 1, 488-494. Doi: 10.1890/15409295(2003)001[0488:RDECAR]2.0.CO;2).

[17] Folke, C. (2006). Resilience: The emergence of a perspective for social-ecological systems analyses. Global Environmental Change 16(3), 253-267. Doi: 10.1016/j.gloenvcha.2006.04.002.

[18] Folke, C., Carpenter, S., Elmqvist T., Gunderson, L., Holling, C. S. \& Walker, B. (2002). Resilience and Sustainable Development: Building Adaptive Capacity in a World of Transformations. AMBIO: A Journal of the Human Environment 31(5), 437-440. Doi: 10.1579/0044-7447-31.5.437.

[19] Fonte, M. (2006). Slow Food's Presidia: what do small producers do with big retailers Research in Rural Sociology and Development, 12, 203-240. Doi: 10.1016/S10571922(06)12009-0.

[20] Fraser, E. D. G., Mabee, W. \& Slaymaker, O. (2003). Mutual dependence, mutual vulnerability: the reflexive relation between society and the environment. Global Environmental Change, 13(2), 137-144. Doi: 10.1016/S0959-3780(03)00022-0.

[21] Garmestani, A. S., Allen, C. R., Mittelstaedt, J. D., Stow, C. A. \& Ward, W. A. (2006). Firm size diversity, functional richness, and resilience. Environmental and Development Economics, 11(4), 533-551. Doi: 10 .1017/S1355770X06003081.

[22] Heijman, W., Hagelaar, G. \& Heide, M. v.d. (2007). Rural resilience as a new development concept. EAAE seminar Serbian Association of Agricultural Economists Novi Sad, Serbia. Last accessed 5 January 2012.2 Retrieved from: http://portal.zzbaco.com/mojo_baco/Data/Sites/1/docs/mono/EAAE/C/52\%20SC\%20Heijm an_Wim.pdf.

[23] Hill, M. (1973). Diversity and Evenness: a Unifying Notation and its Consequences. Ecology, 54(2), 427-432. Doi: 10.2307/1934352.

[24] Horlings, L. G., Marsden, T. K. (2011). Towards the real green revolution? Exploring the conceptual dimensions of a new ecological modernisation of agriculture that could 'feed the world'. Global Environmental Change, 21(2), 441-452. Doi: 10.1016/j.gloenvcha.2011.01.004.

[25] Ives, A. R. \& Carpenter, S. R. (2007). Stability and diversity in ecosystems. Science, 317(5834), 58-62. Doi: 10.1126/science.1133258.

[26] Janssen, M. A. \& Anderies, J. M. (2007). Robustness-tradeoffs for social-ecological systems. International Journal of the Commons, 1(1), 43-66.

[27] Janssen, M. A., Anderies, J. M. \& Ostrom, E. (2007). Robustness of social-ecological systems to spatial and temporal disturbances regimes. Society and Natural Resources, 20(4), 307-322. Doi: 10.1080/08941920601161320.

[28] Sachs, J. D. \& Warner, A. M. (1995). Natural Resource Abundance and Economic Growth. NBER Working Papers 5398. Cambridge (MA): National Bureau of Economic Research, Inc.

[29] Junge, K. (1994). Diversity of ideas about diversity measurement. Scandinavian Journal of Psychology, 35(1), 16-26. Doi: 10.1111/j.1467-9450.1994.tb00929.x.

[30] Kempener, R., Kaufman, P., Stagl, S., Stirling, A. \& Perez, K. (2009). Teresa - Diversity and Resilience of Rural Areas [Research report]. Brighton: University of Sussex.

[31] Kinzig, A. P., Pacala, S. (2002). Successional biodiversity and eco system functioning (pp. 175-212). In Kinzig, A. P., Pacala, S. \& Tilman, D., eds., Functional consequences of biodiversity: empirical progress and theoretical extensions. Princeton (NJ): Princeton University Press. 
[32] Kirman, A. (1992). Variety: the coexistence of techniques. Revue d'Économie Industrielle, 59(1), 62-74.

[33] Lietaer, B., Ulanowicz, R. E., Goerner, S. J. \& McLaren N. (2010). Is our monetary structure a systemic cause for financial instability? Evidence and remedies from nature. Journal of Futures Studies, 14(3), 89-108.

[34] Lin, B. B. (2011). Resilience in Agriculture through Crop Diversification: Adaptive Management for Environmental Change. BioScience, 61(3), 183-193. Doi: 10.1525/bio.2011.61.3.4.

[35] Low, B., Ostrom, E., Simon, C. \& Wilson, J. (2003). Redundancy and diversity: Do they influence optimal management? (pp. 83-114). In: Berkes, F., Colding, J. \& Folke, C., eds., Navigating social-ecological systems: building resilience for complexity and change. Cambridge University Press.

[36] Marsden, T. (2009). Mobilities, Vulnerabilities and Sustainabilities: Exploring Pathways from Denial to Sustainable Rural Development. Sociologia Ruralis, 49(2), 113-131. Doi: 10.1111/j.1467-9523.2009.00479.x.

[37] McCann, K. (2000). The diversity-stability debate. Nature 405(6783), 228-233. Doi: $10.1038 / 35012234$.

[38] McCann, K. (2007). Protecting Bio-structure. Nature 446(7131), 29. Doi: 10.1038/446029.

[39] Mclntosh, R. (1967). An Index of Diversity and the Relation of Certain Concepts to Diversity. Ecology, 48(3), 392-404. Doi: 10.2307/1932674.

[40] Metcalfe, J. (1992). Variety, Structure and Change: an evolutionary perspective on the competitive process. Revue d'Économie Industrielle, 59(1), 46-61.

[41] Metcalfe, J. \& Gibbons, M. (1989). Technology, Variety and Organization: a Systematic Perspective on the Competitive Process. Research on Technological Innovation, Management and Policy, 4,153-193.

[42] Naeem, S., Bunker, D. E., Hector, A., Loreau, M. \& Perrings, C., eds. (2009). Biodiversity, Ecosystem Functioning, and Human Wellbeing: An Ecological and Economic Perspective. Oxford Univ. Press.

[43] Nelson, M. C., Hegmon, M., Kulow, S. R., Peeples, M. A., Kintigh, K. W. \& Kinzig, A. P. (2011). Resisting Diversity: a Long-Term Archaeological Study. Ecology and Society, 16(1): 25. http://www.ecologyandsociety.org/vol16/iss1/art25/.

[44] Ostrom, E. (2005). Understanding Institutional Diversity. Princeton: Princeton University Press, New Jersey, USA.

[45] Quaranta, G. \& Salvia, R. (2000). Peasant agriculture and part-time farming: use of resources and landscape effects in a rural area of Southern Italy. Medit, 11(1), 41-45.

[46] Reidsma, P. \& Ewert F. (2008). Regional farm diversity can reduce vulnerability of food production to climate change. Ecology and Society 13(1): 38. URL: http://www.ecologyandsociety.org/vol13/iss1/art38/.

[47] Schouten, M., Heide, M. v.d. \& Heijman, W. (2009). Resilience of Social-Ecological Systems in European Rural Areas: Theory and Prospects. EAAE Seminar "The Role of Knowledge, Innovation and Human Capital in Multifunctional Agriculture and Territorial Rural Development", Belgrade December 2009. Last accessed 5 January 2012 http://ageconsearch.umn.edu/bitstream/57343/2/Schouten\%20Marleen\%20cover.pdf

[48] Simpson, E. H. (1949). Measurement of Diversity. Nature, 163, 688. Doi: $10.1038 / 163688 a 0$.

[49] Stirling, A. (1999). On the economics and analysis of diversity. Mimeo, SPRU Electronic Working Paper, n. 28. Brighton: University of Sussex. 
[50] Stirling, A. (2007). A general frame work for analyzing diversity in science, technology and society. Journal of the Royal Society Interface 4(15), 707-719, doi: 10.1098/rsif.2007.0213.

[51] Ulanowicz, R. E., Goerner, S. J., Lietaer, B. \& Gomez, R. (2009). Quantifying sustainability: resilience, efficiency and the return of information theory. Ecological Complexity 6(1), 2736. Doi: 10.1016/j.ecocom.2008.10.005.

[52] Van Der Ploeg, J. D., Renting, H., Brunori, G., Knickel, K., Mannion, J., Marsden, T., De Roest, K., Sevilla-Guzmán, E. \& Ventura, F. (2000). Rural Development: From Practices and Policies towards Theory. Sociologia Ruralis 40(4), 391-408. Doi: 10.1111/14679523.00156.

[53] Wagner, J. E. (2002). Regional Economic Diversity: Action, Concept, or State of Confusion. Journal of Regional Analysis and Policy, 30 (2), 1-22.

[54] Wagner, J. E. \& Deller, S. C. (1998). Measuring the Effects of Economic Diversity on Growth and Stability. Land Economics, 74(4), 541-556.

[55] Walker, B. H., Gunderson, L. H., Kinzig, A. P., Folke, C., Carpenter, S. \& Schultz, L. (2006). A handful of heuristics and some propositions for understanding resilience in social-ecological systems. Ecology and Society, 11(1): 13. Last accessed 5 January 2012 http://www.ecologyandsociety.org/vol11/iss1/art13/.

[56] Walker, B. H., Kinzig, A. P. \& Langridge, J. (1999). Plant attribute diversity, resilience, and ecosystem function: the nature and significance of dominant and minor species. Ecosystems, 2(2), 95-113. Doi: 10.1007/s100219900062.

[57] Waring, T. M. 2011. Ethnic forces in collective action: diversity, dominance, and irrigation in Tamil Nadu. Ecology and Society 16(4): 1. http://dx.doi.org/10.5751/ES-04265-160401

[58] Wilson, G. A. (2012). Community resilience and environmental transitions. London: Earthscan. 